\title{
A Comparison of Lucigenin - Free Oxygen Radicals in Reactive Hyperplasia and Recurrent Tonsillitis
}

\author{
Reaktif Hiperplazi ve Rekürrent Tonsillitlerde Lusigenin - Serbest Oksijen Radikallerinin \\ Karşılaştırılması
}

\section{Resuli AS}

İstanbul Yeni Yüzyıl Üniversitesi-Kulak Burun Boğaz Anabilim Dalı, İstanbul, TURKEY

\begin{abstract}
Aim: Today, tonsillectomy (T) used for chronic tonsillitis is among the most common surgery type that ear nose, and throat physicians perform. The differences in the pathogenesis of chronic tonsillitis and tonsil hypertrophy are still unknown. This study aimed to compare the levels of free oxygen radicals in patients with tonsil hypertrophy and chronic tonsillitis and to investigate the role of free oxygen radicals in the pathogenesis of chronic tonsillitis.

Materials and Method: The study included 40 patients who had chronic tonsillitis indications based on Paradise criteria, and $T$ was performed. Operation materials were histopathologically examined, and their free oxygen radicals (FOR) levels were measured.

Results: Based on the histopathological results, the participants were divided into two groups: one including 28 (70\%) patients who had active or chronic tonsillitis, the other including 12 (30\%) patients with reactive follicular hyperplasia. Lucigenin - free oxygen radicals (Luc-FOR) levels of the group with chronic

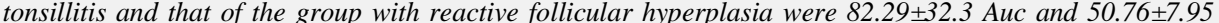
Auc, respectively. Luc-FOR values were found to be significantly higher in the group with chronic tonsillitis $(p=0.001)$.

Conclusion: Free oxygen radicals play an essential role in tonsillar pathologies. Differences in the LucFOR levels measured from tonsillar tissue in patients with tonsil hypertrophy and chronic tonsillitis demonstrate that the pathogenesis of these two diseases is different.

ÖZET

Giriș ve Amaç: kronik tonsilite bağlı Tonsillektomi (T), Kulak Burun Boğaz hekimlerinin en sık yaptıkları ameliyatlardandir. Halen kronik tonsillit ve tonsil hipertrofisi patogenizindeki faklılıklar tam olarak bilinmemektedir. Tonsil hipertrofisi ve kronik tonsillit hastalarinda serbest okisjen radikallerinin seviyelerinin karşılaştırılması ve serbest okisjen radikallerinin kronik tonsiillit patogenezindeki rolünün araştırılması bu çalışmada amaçlanmıştır.

Gereç ve yöntem: Çalışmaya Paradise kriterlerine göre Tonsillektomi (T) endikasyonu konulan ve opere edilen 40 hasta alınd. Operasyon materyallerine histopatolojik inceleme ve serbest oksijen radikalleriden süperoksit ölçümleri yapıldl.

Bulgular: Histopatolojik bulgulara göre; 28 (\%70) hastadan oluşan aktif yada kronik tonsilitli diğeri ise 12 (\%30) hastadan oluşan reaktif folliküler hiperplazili olarak iki gruba ayrildı. Kronik tonsilitli grubun lusigenin-serbest oksijen radikal (Luc-SOR) değeri 82.29+-32.3 Auc, reaktif folliküler hiperplazi'li grubun ise 50.76+-7.95 Auc bulundu. Luc-SOR değeri karşılaştırıldığında kronik tonsillitli grupta anlamlı derecede ( $p=0.001)$ yüksek olduğu belirlendi.

Sonuç: Serbest oksijen radikalleri tonsiller patolojilerde önemli rol oynamaktadır. Tonsil hipertrofisi ve kronik tonsillit hastalarının tonsil dokusundan ölçülen Luc-SOR değerlerinin farklı olması bu iki hastalı̆̆ın patogenezinin de farklı olduğunu göstermektedir.
\end{abstract}

\section{INTRODUCTION}

Palatine tonsils, a part of the Waldeyer ring, are the most common cause of upper respiratory tract infections (1). Beta-hemolytic streptococci, Streptococcus pneumonia, and Haemophilus influenza are the most common bacterial agents that cause acute tonsillitis (2, 3). Characteristic symptoms of acute tonsillitis are sudden onset of fever, painful cervical lymphadenopathy with sore throat and erythematous tonsils including yellow-white purulent exudate in the
Key Words:

Tonsillectomy,

Chronic tonsillitis,

Free oxygen radicals.

Anahtar Kelimeler:

Tonsillektomi,

Kronik tonsilit,

Serbest oksijen radikalleri. crypts. Symptoms of chronic tonsillitis include having acute tonsillitis attacks for 4 or 5 times a year, feeling of continuous throat pain, difficulty in swallowing, weakness, atrophy and/or hypertrophy in tonsils and tonsil magma (4). The host first responds with polymorphonuclear leukocytes (PMNL) and antibodies during the chronic process. Then, as a result of the complex interaction between pathogenic bacteria and the host immune response, cytokines, prostanoids, and proteinases, causing local and systemic tissue damage,

Correspondence: Ali Seyed Resuli, MD Eski Edirne Asfaltı No:653 Bahat Hastanesi Sultangazi/Istanbul/Türkiye E-mail: a.s.resul@hotmail.com Phone: 05322647435

Cite this article as: Resuli AS. A Comparison of Lucigenin - Free Oxygen Radicals in Reactive Hyperplasia and Recurrent Tonsillitis. Phnx Med J. 2019;1(1):15-19. 
are secreted by PMNLs (5). PMNLs produce free oxygen radicals (FOR) during the bacterial phagocytosis. Neutrophils show their antimicrobial effects in two different mechanisms. These are oxygendependent and oxygen-independent mechanisms. The generation of FOR with oxygen-dependent mechanism begins with activation of Nicotinamide Adenine Dinucleotide Phosphate-H (NADPH) oxidase enzyme in the plasma membrane of PMNLs (6). PMNLs are produced by stimulation of the bacterial antigen, and superoxide and hydrogen peroxide radicals are produced by catalyzing the NADPH enzyme during phagocytosis (7). Oxygen-independent mechanism does not include oxygen molecule consumption and obsolete oxygen metabolites (8). FOR can occur both in regular metabolic events in organisms and during phagocytosis, especially in chronic infections (9).

Tonsillary pathologies have two different diseases: chronic tonsillitis and tonsillar hypertrophy. Although these two diseases originate from the same tissue, they show different clinical and different histopathological findings (10). Furthermore, the pathogenesis of these two diseases and the role of free oxygen radicals in this pathogenesis have not been elucidated. This study aimed to compare the Lucigenin - free oxygen radicals (Luc-FOR) levels in tonsillectomy specimens by using the chemiluminescence (KL) method in patients with tonsil hypertrophy and chronic tonsillitis and to investigate the role of free oxygen radicals (FOR) in the pathogenesis of chronic tonsillitis.

\section{MATERIAL AND METHODS}

The study included 40 patients who were admitted to our clinic with the complaint of tonsillitis between 2010 and 2018. The participants met Paradise criteria, and they did not smoke (11). All patients were performed $\mathrm{T}$ under general anesthesia. During the period when the operation was performed, all the patients were protected against acute tonsillitis and/or respiratory tract infection. For histopathological examination, the excised materials were placed in containers containing $10 \%$ formaldehyde, and they were placed in special tubes for FOR analysis. FOR measurement was performed using the KL method. KL is a noninvasive and direct method for the determination of FOR in tissues and cells. KL measurements are carried out using devices called luminometers. Luminometers contain sensitive light detectors. When PMNLs meet bacteria, oxygen consumption increases, and FOR molecules and light energy emerge. Luminometers measure this light energy $(12,13)$. The samples were placed in count tubes containing $0.5 \mathrm{M}$ phosphate-buffered saline (PBS) and $20 \mathrm{mM}$ HEPES. Superoxide radicals were measured using lucigenin (Luc) (Acros Lab., France) in a luminometer (EG and Berthold Junior LB 9509). Counting tubes were placed in the luminometer in oneminute intervals for five minutes, their dry weights were measured, and the area under curve (Auc) rlu/mg tissue was calculated by calculating the area under the curve. In the calculation of this area, the Auc value is determined by taking the integral of the measurement points using the following formula.

Area $=\Delta \mathrm{t}[(\mathrm{y} 1 / 2+\mathrm{y} 2+\mathrm{y} 3+\mathrm{yn}-1+(\mathrm{yn} / 2)]$

$\Delta \mathrm{t}$ : time interval

$\mathrm{n}$ : total number of measurement points

y1,y2,...yn: measurements

Homogeneity of the groups was evaluated using the 'Mann-Whitney U-test,' and the correlations between them were analyzed using the Pearson test. The significance of the results was evaluated at $\mathrm{p}<0.05$.

The study was approved by the Istanbul Yeni Yüzyıl University Ethics Board (Date: January 07, 2019 Decision No: 2019/01).

\section{RESULTS}

In our study, 25 (62\%) patients among 40 whom $\mathrm{T}$ was performed were male, 15 (38\%) were female, and their age was between 15 and 43 years (18.6).

Histopathological examination revealed that 28 (70\%) patients had active or chronic tonsillitis (figure 1), and 12 (30\%) had reactive follicular hyperplasia (figure 2).

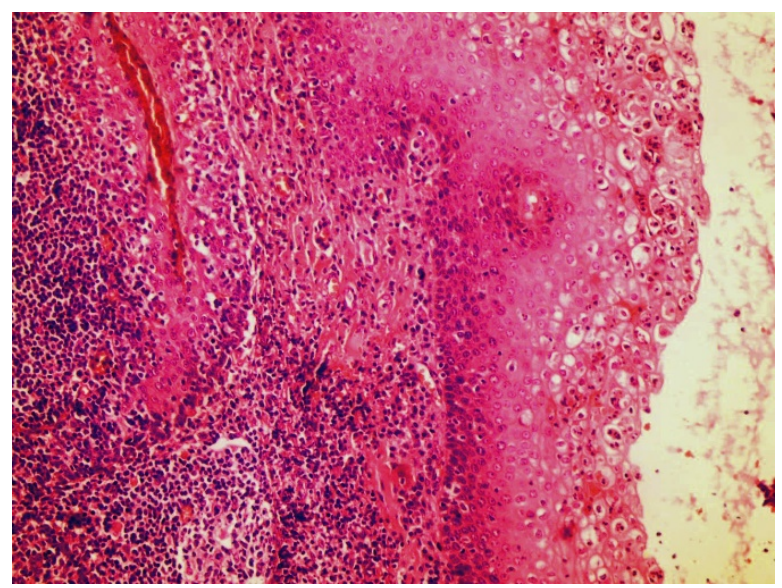

Figure 1:Acute and or chronic tonsillitis (Hematoxylin and eosin staining $\mathrm{X} 40$ )

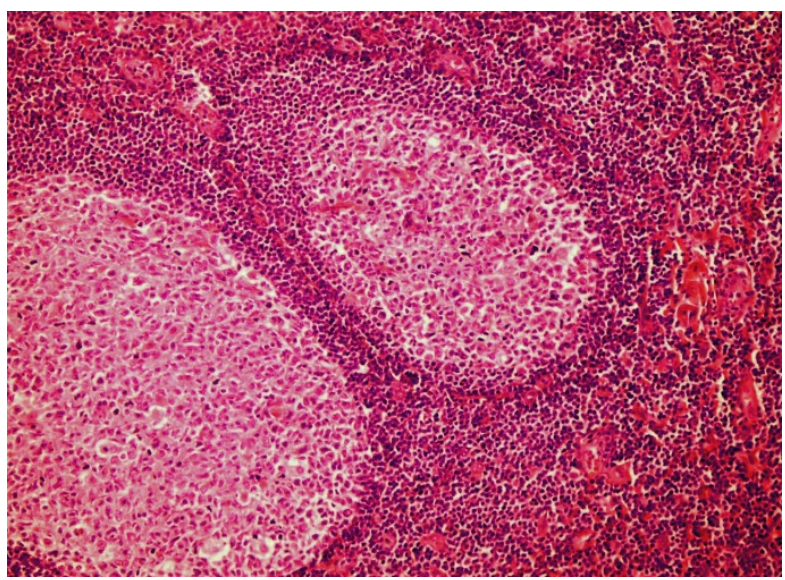

Figure 2:Lymphoid hyperplasia (Hematoxylin and eosin staining X40) 
The patients were divided into two groups based on the histopathological findings, and their Luc-FOR values were examined.

Luc-FOR value of the group with chronic tonsillitis group was $82.29 \pm 32.3$ Auc, and that of the group with reactive follicular hyperplasia was 50.76 \pm 7.95 Auc. It was found that Luc-FOR values were significantly higher in the group with chronic tonsillitis $(p=0.001)$ (Table 1).

\section{DISCUSSION}

Tonsillectomy is still among the most frequently performed operations during childhood in the US and Europe $(14,15)$. In our clinic, $15.4 \%$ of the operations performed between 2010 and 2018 was tonsil operation.

Indications for tonsil operations were classified as i) chronic and/or recurrent tonsillitis, ii) upper respiratory tract obstruction, iii) suspicion of malignancy, iv) other rare causes. Based on the Paradise criteria, the first group consisted of the patients who had acute tonsillitis with fever 7 or more times in the last year, those who had acute tonsillitis with fever 5 or more times in two consecutive years, and those who had acute tonsillitis with fever 3 or more times in following 3 years. Also, all the patients' used antibiotics, and the illness lasted one week $(11,16)$. In our study, we selected patients with chronic tonsillitis based on these criteria.

PMNLs produce a significant amount of FOR in the process of chronic tonsillitis during the bacterial phagocytosis. Molecular oxygen is the primary source of FOR. As a result of the reduction of oxygen, reactive oxygen derivatives such as superoxide, hydrogen peroxide, and hydroxyl radicals emerge. These cytotoxic structures cause oxidative damage in cells. Biological effects of the reactive oxygen species are controlled by enzymatic defense mechanisms such as superoxide dismutase (SOD) (17). The superoxide anion is the most important FOR released from the activated inflamed cells $(18,19)$. Since it cannot penetrate lipid membranes, it does not engage in the systemic circulation and remains where it is produced (9, 20-22). In our study, we showed that the fact that superoxide radical does not engage in the systemic circulation and that it is an important FOR marker in the pathogenesis of chronic tonsillitis, and histopathological findings support this.

Unstable FOR types attack the cells to stabilize and result in various diseases, damaging cell components. The superoxide radical, which has no harmful effect, shows this quality as the source of hydrogen peroxide and the reductor of transition metal ions (23). FOR also react with lipids, proteins, carbohydrates, and DNA to get electron. When the number of these oxidants is too high, they cause peroxidation of the lipids in the membrane leading to disruption of the permeability and, thus, to intracellular ion imbalance. They disrupt the structure of DNA and RNA molecules and play an essential role in the formation of many cancer cells (24).

In our study, we conducted the histopathological examination and measurement of superoxide radical measurements of the operation material of 40 patients who were diagnosed with chronic and/or recurrent tonsillitis and whom $\mathrm{T}$ was applied based on the Paradise criteria. Among the patients, 28 (70\%) had chronic tonsillitis, and 12 (30\%) had reactive follicular hyperplasia. The levels of superoxide radicals were significantly higher in the group with chronic tonsillitis.

In the literature, although there are much researches $(18,25-33)$ investigating the high levels of FOR in tonsillectomy materials, there is only one article conducted by Kiroglu et al. (34) examining the difference of oxidant levels between chronic tonsillitis and tonsil hypertrophy. In this study, under our article, tonsil oxidase (malondialdehyde) and anti oxidase (catalase) levels were found to be significantly high in patients with tonsillitis compared to those with hypertrophy. However, in the same study, no significant difference was found in serum oxidase levels between patients with chronic tonsillitis and tonsillar hypertrophy. This finding shows that the superoxide radical activity is in tonsillar tissue rather than blood. In a study conducted by Cvetkovic et al. (33) investigating the oxidative stress in patients with tonsillar hypertrophy and chronic tonsillitis, lipid peroxidation was found to be higher in the blood levels compared to the control group, moreover no significant difference in lipid peroxidation levels was found between patients with tonsillar hypertrophy and chronic tonsillitis. However, in this study, because only blood levels were examined, the increase in serum levels of oxygen radicals in cases with tonsillar hypertrophy may be due to the stress of the body after exposure to airway obstruction. In other studies in the literature, the relationship between preoperative and postoperative blood levels of oxidants and antioxidants was investigated. In the researches conducted by Shukla et al.(18), Kaygusuz et al. (32) and Yilmaz et al. (31) it was revealed that pre-operative levels of

Table 1: FOR values

\begin{tabular}{|cccc} 
& $\begin{array}{c}\text { The group with active or chronic } \\
\text { tonsillitis }\end{array}$ & $\begin{array}{c}\text { The group with reactive follicular } \\
\text { hyperplasia }\end{array}$ & P \\
\hline Luc.FOR & $86.29 \pm 32.3$ Auc & $50.76 \pm 7.95$ Auc & 0.001 \\
\hline Luc.: lucigenin & FOR: free oxygen radicals Auc: area under the curve & & \\
\hline
\end{tabular}


malondialdehyde increased significantly compared to post-operative because of oxidative stress due to inflammation after tonsillectomy and it was shown that serum SOD levels decreased after surgery. In the study conducted by Yilmaz et al. (31), FOR levels decreased after $\mathrm{T}$ but did not reach the level of healthy patients in the long term. In this study, it is recommended that perioperative antioxidant treatment should be discussed for the faster recovery of patients. However, in a similar survey by Dogruer et al. (30), although serum malondialdehyde levels decreased after $\mathrm{T}$ compared to pre-operative levels, SOD levels did not change significantly. This was attributed to defense mechanisms on antioxidant levels as a result of longterm exposure to hypoxia. According to Shukla et al. (35), antioxidant therapy is as effective as tonsillectomy, and the application of perioperative antioxidant treatment should be discussed.

In conclusion, few studies are investigating the role of FOR in the pathogenesis of tonsillar hypertrophy and chronic tonsillitis. In our research, it was shown in parallel with previous studies that tonsillar FOR levels were higher in patients with chronic tonsillitis compared to patients with tonsillar hypertrophy and the pathogenesis of tonsillar hypertrophy and chronic tonsillitis were different even if they originated from the same tissue. The role of the tonsil tissue FOR levels in determining the correct tonsillectomy indication should be discussed in further researches.

\section{Conflicts of Interest \\ All other co-authors have no conflicts of interest}

Acknowledgments

The author would like to thank; Bahat Hospital chief physician Dr. Hamza Bahat, Dr. Ayda Karabulut, Dr. Nedim Polat, and İstanbul Yeni Yüzyıl University.

\section{REFERENCES}

1. Wagner S, J.H., Nau F, Schmitt HJ. Relevance of infectious diseases in pediatric practice. Klin Pediatr. 1993 Jan-Feb;205(1):14-7. https://doi: 10.1055/s-2007-1025190

2. Cowan DL, H.J.A.a.c.i.o.p.a.t., Scott Brown’s Otolaryngology, Volume 5, Chapter 4, 6th edition, 1997.

3. Piacenti GL, P.D., Blasi F, et al. Atypical bacteria in adenoids and tonsillitis of children requiring adenotonsillectomy. Acta Otolaryngol. 2010; 130(5): 620-5. https://doi: 10.3109/00016480903359921.

4. Bicknell PG. Role of adenotonsillectomy in the management of pediatric ear, nose and throat infections. Pediatr Infect Dis J 1994; 13(1 Suppl 1): S75-8.

5. Gustafsson A, İ.H., Asman B, Bergstrom K. (2006). Hyper-reactive mononuclear cells and neutrophils in chronic periodontitis. J Clin Periodontol, 33:126-129. https://doi: 10.1111/j.1600-051X.2005.00883.x.

6. Arvind P, M.K., Diana O, Sanjay B. NADPH oxidases: an overview from structure to innate immunity-associated pathologic. Cell Molec İmmunol. 2015;12:5-23. https://doi: 10.1038/cmi.2014.89.

7. Claesson R, J.E., Carlsson J.(1994). Oxygen-dependent modulation of release and activity of polymorphonuclear leukocyte granule products. Oral Microbiol Immunol, 9:81-87.https://doi.org/10.1111/j.1399-302X.1994.tb00039.x.

8. Dennison DK, Van Dayke TE.(1997). The acute inflammatory response and the role of phagocytic cells in periodontal health and disease. Periodontol 2000, 14:54-78.

9. $\quad$ Cheeseman KH, Slater TF. (1993): An introduction to free radical biochemistry. Brit Med Bull 49(3):481-493. https://doi.org/10.1093/oxfordjournals.bmb.a072625

10. Kutluhan, A., et al., Differences in clinical and histopathologic features between chronic adenotonsillitis and chronic adenotonsillar hypertrophy. Kulak burun bogaz ihtisas dergisi: KBB= Journal of ear, nose, and throat, 2003. 10(2): p. 61-67.

11. Paradise JL, B.C., Bachman RZ, Colborn DK, Bernard BS, Tatlor FH, Rogers KD, Schwarzbach RH, Stool SE, Friday GA, et al. Efficacy of tonsillectomy for recurrent throat infection in severely affected children. Results of parallel randomized and nonrandomized clinical trials. N Engl J Med. 1984 Mar 15;310(11):674-83. https://doi: 10.1056/NEJM198403153101102.

12. Münzel T, A.e.İ., Kleschyov AL, Harrison DG. (2002). Detection of superoxide in vascular tissue. Arterioscler Thromb Vasc Biol, 22:1761-1768.https://doi: 10.1161/01.ATV.0000034022.11764.EC

13. Davies GR, S.N., Stevens TRJ, Grandison A, Blake DR Rampton DS. (1992). Mucosal reactive oxygen metabolite production in duodenal ulcer disease. Gut, 33:1476-1472.

14. Erickson BK, L.D., St Sauver JL, et al. Changes in incidence and indications of tonsillectomy and adenotonsillectomy, $1970-2005$ Otolaryngol Head Neck Surg 2009; 140:894-901. https://doi: 10.1016/j.otohns.2009.01.044.

15. Faramarzi A, K.M., Heydari ST, Tavasoli M. Assessment of the consensus about tonsillectomy and/or adenoidectomy among pediatricians and otolaryngologists. İnt J Pediatr Otorhinolaryngol 2010; 74:133-136. https://doi: 10.1016/j.ijporl.2009.10.024.

16. Baugh RF, A.S., Mitchell RB, et al. Clinical practice guideline: tonsillectomy in children. Otolaryngol Head Neck Surg 2011; 144(I suppl): S1-30. https://doi.org/10.1177/0194599810389949.

17. İnal ME., K.G., Sunal E. Antioxidant enzyme activities and malondialdehyde levels related to aging. Clin Chim Acta 2001; 305:75-80.

18. Shukla GK, M.A., Pandey S, et al. A study of free radicals and scavenging enzyme in tonsillitis. Boll Chim Form 1996-135:6535.https://doi: 10.1016/S0194-5998(03)00630-2

Delibaş N, D.H., Döner F, Gedikli O, Tarhan V. Presbiakuzi ve serbest radikaller. Kulak Burun Boğaz ve Baş Boyun Cerrahisi Dergisi. 1996; 4:811. 


\section{Phnx Med J. November, Volume 1 No 1}

20

Chapple ILC, Matthews JB.(2007). The role of reactive oxyge 43;160-232. https://doi: 10.1111/j.1600-0757.2006.00178.x

Nordberg J, A.E.R.o.s., antioxidants, and the 1312.https://doi.org/10.1016/S0891-5849(01)00724-9.

Battino M, B.P., Wilson M, Newman H.(1999). Oxidative injury and inflammatory periodontal diseases: the challenge of anti-oxidants to free radicals and reactive oxygen species. Crit Rev Oral Biol Med, 10(4):458-476.https://doi: 10.1177/10454411990100040301.

Sardesal VM. Role of antioxidants in health maintenance. Nutr Clin Pract 1995; 10: 19-25. https://doi: 10.1177/011542659501000119.

Levine AS, S.L., Tan R, et al. The oxidative DNA damage response: a review of research undertaken with Tsinghua and Xiangya students at the University of Pittsburg. Sci China Life Sci. 2017;60:1077-1080.https://doi: 10.1007/s11427-017-9184-6. .

Park, S.-N., et al., Superoxide dismutase in pediatric palatine tonsils and adenoids and its related clinical parameters. American journal of otolaryngology, 2003. 24(5): p. 323-327.

Cemek, M., et al., Investigation of antioxidant status in children with acute otitis media and tonsillitis. International journal of pediatric otorhinolaryngology, 2004. 68(11): p. 1381-1385.

Cemek, M., et al., Oxidant and antioxidant levels in children with acute otitis media and tonsillitis: a comparative study. Internationa journal of pediatric otorhinolaryngology, 2005. 69(6): p. 823-827.

Garca, M.F., et al., Assessment of adenosine deaminase (ADA) activity and oxidative stress in patients with chronic tonsillitis. European Archives of Oto-Rhino-Laryngology, 2014. 271(6): p. 1797-1802.

Ozbay, I., et al., Advanced oxidation protein product levels as a marker of oxidative stress in pediatric patients with chronic tonsillitis Acta Otorhinolaryngologica Italica, 2016. 36(5): p. 381

Doğruer, Z.N., et al., Malondialdehyde and antioxidant enzymes in children with obstructive adenotonsillar hypertrophy. Clinical biochemistry, 2004. 37(8): p. 718-721.

Yılmaz, T., E.G., Koçan, and H.T. Besler, The role of oxidants and antioxidants in chronic tonsillitis and adenoid hypertrophy in children International journal of pediatric otorhinolaryngology, 2004. 68(8): p. 1053-1058

Kaygusuz, I., et al., Free radicals and scavenging enzymes in chronic tonsillitis. Otolaryngology-Head and Neck Surgery, 2003. 129(3): p. 265-268.

Cvetković, T., et al., Investigation of oxidative stress in patients with chronic tonsillitis. Auris Nasus Larynx, 2009. 36(3): p. 340-344.

Kiroglu, A.F., et al., Oxidants and antioxidants in tonsillar and adenoidal tissue in chronic adenotonsillitis and adenotonsillar hypertrophy in children. International journal of pediatric otorhinolaryngology, 2006. 70(1): p. 35-38.

Shukla, G., et al. Comparative status of oxidative damage and antioxidant enzymes in chronic tonsillitis patients. Bollettino chimico

farmaceutico, 1998. 137(6): p. 206-209. 